\title{
Evidence that non-caspase proteases are required for chromatin degradation during apoptosis
}

\author{
Francis M. Hughes $\mathrm{Jr}^{1}$, Rosemary B. Evans-Storms ${ }^{1}$, and \\ John A. Cidlowski ${ }^{1,2}$ \\ ${ }^{1}$ Laboratory of Signal Transduction, National Institute of Environmental Health \\ Sciences, National Institutes of Health, Research Triangle Park, North Carolina \\ 27709, USA \\ 2 corresponding author: J.A. Cidlowski, P.0. Box 12233; MD E2-02, Research \\ Triangle Park, NC 27709. tel: 919-541-0788; fax: 919-541-1367; e-mail; \\ Cidlowski@niehs.nih.gov
}

Received 6.2.98; revised 23.4.98; accepted 15.5.98

Edited by G. Melino

\begin{abstract}
Chromatin degradation into oligonucleosomal and $\approx 30$ $50 \mathrm{~Kb}$ fragments is a hallmark of apoptosis. Crude nuclear extract from apoptotic rat thymocytes is able to recapitulate both types of DNA fragmentation in an assay using HeLa cell nuclei as an exogenous substrate. Using size exclusion chromatography we have identified a novel activity $(\approx 260 \mathrm{Kd})$ that produces only $\approx 30-50 \mathrm{~Kb}$ DNA fragments, and a $25 \mathrm{Kd}$ activity that generates both $\approx 30-50 \mathrm{~Kb}$ and oligonucleosomal fragments. Both activities produced DNA fragments with $3^{\prime}-\mathrm{OH}$ termini, are dependent on $\mathrm{Ca}^{2+}$ and $\mathrm{Mg}^{2+}$ and are inhibited by $\mathrm{N}$-ethyl-maleimide, sodium tetrathionate, aurintricarboxylic acid and sodium chloride, similar to other nucleases implicated in apoptosis. These activities were inhibited by the serine protease inhibitors N-tosyl-Lphenylalanine chloromethyl ketone and $\mathrm{N} \alpha$-p-tosyl-L-lysine chloromethyl ketone, but not by the serine protease inhibitor diisopropyl fluorophosphate, or by calpain inhibitors I or II, or the capsase inhibitors Ac-Asp-Glu-Val-Asp-aldehyde, Ac-TyrVal-Ala-Asp-aldehyde, or Z-Val-Ala-Asp-fluoromethyl ketone. Both activities were insensitive to protease inhibitors when extracts were incubated with naked linear DNA, indicating the presence of both nuclease and protease activities in the preparation. Together, these observations suggest the involvement of non-caspase proteases in apoptosis which perhaps function by altering chromatin substructure and exposing it to nucleolytic attack.
\end{abstract}

Keywords: apoptosis; endonuclease; protease; caspase

Abbreviations: MARS, matrix attachment regions: ICE, interleukin$1 \beta$ converting enzyme: DEX, dexamethasone, NEM, N-ethylmaleimide: NaTT, sodium tetrathionate: ATC, aurintricarboxylic acid: TPCK, tosyl-L-phenylalanine chloromethyl ketone: TLCK, N $\alpha$ p-tosyl-L-lysine chloromethyl ketone: DFP, diisopropyl fluorophosphate: Cal1, Calpain Inhibitor I: Cal2, Calpain Inhibitor II: DEVDald, Ac-Asp-Glu-Val-Asp-aldehyde: YVAD-ald, Ac-Tyr-Val-Aspaldehyde: VAD-fmk (Z-Val-Ala-Asp-fluoromethyl ketone)

\section{Introduction}

Apoptosis is associated with a number of distinct morphological changes including cell shrinkage, chromatin degradation and cytoplasmic and nuclear condensation and blebbing. Numerous biochemical alterations are associated with these morphological alterations and appear to be signal and celltype independent. The two best known biochemical changes are increases in nuclease and protease activity. Cleavage of chromatin into oligonucleosomal fragments, which form the well-known apoptotic ladder, has been documented in hundreds of cell death models, underscoring its importance to the death process. Chromatin degradation represents a clear irreversible step in apoptosis and thus an understanding of this process is critical to elucidating how the cell becomes irrevocably committed to the death process.

Despite the intensive study of internucleosomal DNA fragmentation during apoptosis, a consensus has not been reached regarding the nuclease(s) responsible. Several candidates have been proposed including NUC18/cyclophilin (Montague et al, 1997), nuc-40 (Deng and Podack, 1995), nuc-58 (Deng and Podack, 1995), DNase I (Peitsch et al, 1994), DNase II (Eastman, 1994), DNase $\gamma$ (Shiokawa et al, 1994), ILCME (Khodarev and Ashwell, 1996), a $25 \mathrm{Kd}$ activity (Schwartzman and Cidlowski, 1993), a $97 \mathrm{Kd}$ molecule (Pandey et al, 1997) and a caspase-activiated DNase (CAD) (Enari et al, 1998). There have also been several apoptotic models described in which internucleosomal DNA degradation does not occur (reviewed in Hughes and Cidlowski, 1996). The existence of such models led to the discovery that DNA is also degraded into $\approx 30-50 \mathrm{~Kb}$ fragments during apoptosis (Oberhammer et al, 1993). As with oligonucleosomal fragments, the nuclease(s) responsible for such cleavage has not been conclusively identified, although our lab has identified a nuclease (NUC18) that is highly homologous to cyclophilin and is activated during apoptosis induced in thymocytes by glucocorticoid (Montague et al., 1997). Recombinant cyclophilin can generate $\approx 30-50 \mathrm{~Kb}$ fragments in exogenous chromatin in a $\mathrm{Mg}^{2+}$. dependent manner but does not cleave DNA internucleosomally, suggesting that NUC18 can account for only a portion of the DNA fragmentation that occurs during apoptosis (Hughes and Cidlowski, 1997; Montague et al, $1997)$. Other investigators have also proposed that $\approx 30-$ $50 \mathrm{~Kb}$ and oligonucleosomal DNA degradation are mediated by separate nucleases. $\approx 30-50 \mathrm{~Kb}$ DNA fragment production requires only $\mathrm{Mg}^{2+}$ for activity whereas the internucleosomal DNA cleavage requires both $\mathrm{Ca}^{2+}$ and $\mathrm{Mg}^{2+}$ (Sun and Cohen, 1994; Walker et al, 1994, reviewed in Hughes and Cidlowski, 1996).

Upstream of DNA fragmentation there is a clear involvement of proteases in cell death. Early studies from our laboratory have previously shown that apoptosis is associated with both a general increase in proteolysis as 
well as a specific increase in the activity of certain serine proteases (reviewed in Hughes and Cidlowski, 1996). Additional studies have also implicated serine proteases in apoptosis. For example, Chang and Eisen (1980) have found that the serine protease inhibitor tosyl-L-phenylalanine chloromethyl ketone (TLCK) prevented the death of target cells attacked by cytotoxic lymphocytes. This same serine protease inhibitor also blocked apoptosis induced by etoposide in HL-60 cells and by bile acid in hepatocytes (Kaufmann et al, 1993; Kwo et al, 1995). Likewise, apoptosis can be prevented in thymocytes by the serine protease inhibitors phenylmethylsulfonyl fluoride, dichloro-isocoumarin and tosyl-L-phenylalanine chloromethyl ketone (TPCK) (Walker and Sikorska, 1993). Clearly serine proteases play an important role in many models of cell death.

Recent data has also implicated members of the interleukin-1 $\beta$ converting enzyme (ICE) family of cysteine proteases (caspases) in many models of apoptosis and suggested these proteases align in a cascade that amplifies a death signal while destroying structural proteins and functional systems (Martin and Green, 1995; Whyte, 1996). Additional proteases, such as the neutral protease calpain (Squier and Cohen, 1997), have also been implicated in cell death.

Despite the clear involvement of proteases in apoptosis and their placement upstream of nuclease activity, the exact relationship between proteolytic activity and DNA degradation remains unclear. Recently, a molecule (DNA Fragmentation Factor; DFF) has been identified that is cleaved and activated by upstream proteases and is sufficient to trigger downstream DNA degradation in a cell-free system (Liu et al, 1997). The murine homolog of this factor has been cloned (known as ICAD) and binds directly to a nuclease (CAD) (Enari et al, 1998). Cleavage of ICAD releases and activates CAD which translocates to
A.

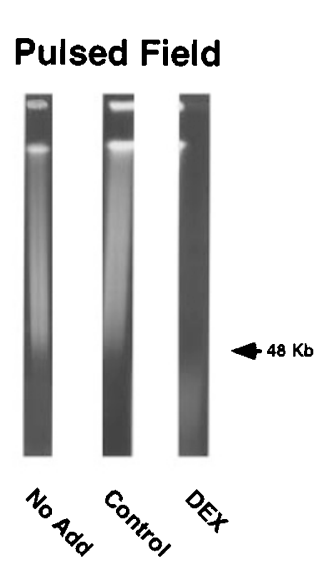

B.
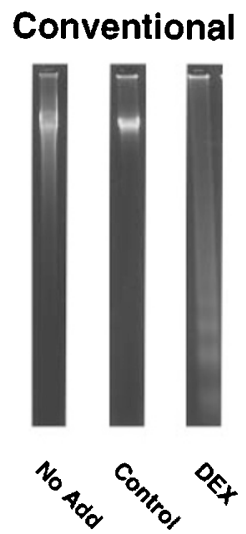

Figure 1 HeLa nuclei assay of nuclear extract from apoptotic thymocytes. Thymocyte nuclear extract $(50 \mu \mathrm{g})$, prepared from uninjected rats (Control) or rats injected $4 \mathrm{~h}$ previously with $5 \mathrm{mg} / \mathrm{Kg}$ dexamethasone (DEX), was analyzed in the HeLa nuclei assay for the ability to facilitate the production of $\approx 30-$ $50 \mathrm{~Kb}$ and oligonucleosomal fragments from HeLa chromatin. (A) Pulsed Field gel electrophoresis of DNA from HeLa nuclei after incubation without additions, or with control or DEX nuclear extract. (B) Conventional agarose ge electrophoresis depicting the low molecular weight chromatin fragmentation patterns produced in the HeLa nucleic assay the nucleus and is capable of internucleosomal DNA fragmentation. The prevalence of this system in apoptotic models is unknown and it remains unclear if proteases play additional roles in DNA degradation such as preparing the chromatin for nucleolytic attack.

In the present study we have examined the role proteases play in the ability of nuclear extracts to generate oligonucleosomal and $\approx 30-50 \mathrm{~Kb}$ DNA fragments. We have identified two separable activities in these extracts, a novel $\approx 260 \mathrm{Kd}$ activity (a large fragment cleavage activity) which exclusively produces $\approx 30-50 \mathrm{~Kb}$ DNA fragments, and a second $\approx 25 \mathrm{Kd}$ activity (internucleosomal cleavage activity) that produces both oligonucleosomal and $\approx 30-$ $50 \mathrm{~Kb}$ DNA fragments. Characterization of both activities indicates they produce DNA fragments with $3^{\prime}-\mathrm{OH}$ termini, are dependent on both $\mathrm{Ca}^{2+}$ and $\mathrm{Mg}^{2+}$ for activity, and are sensitive to thiol-modifying agents. Both fractions possess inherent nuclease and serine protease activities, suggesting a role for non-caspase proteases in the preparation of chromatin for nuclease attack.

\section{Results}

\section{Chromatin degradation by thymocyte nuclear extracts}

To determine if thymocyte nuclear extracts possess all the necessary components to mediate both $\approx 30-50 \mathrm{~Kb}$ and oligonucleosomal fragmentation, we assessed the production of both fragment types using an exogenous chromatin substrate (HeLa nuclei). As shown in Figure 1, in the absence of added extract (No Add), no oligonucleosomal fragmentation or production of $\approx 30-50 \mathrm{~Kb}$ fragments were observed in the HeLa chromatin. A similar pattern was seen with extracts from nondying thymocytes (Control). However, nuclear extract from apoptotic (in vivo dexamethasonetreated) thymocytes facilitated the production of both $\approx 30-$ $50 \mathrm{~Kb}$ and oligonucleosomal fragments, suggesting that these crude nuclear extracts possess all the components necessary to mediate both types of DNA degradation seen during apoptosis in thymocytes in vivo.

\section{Gel filtration of nuclear extracts}

To investigate the complexity and specificity of chromatin degrading activities present in nuclear extracts from apoptotic (in vivo dexamethasone-treated) thymocytes, we fractionated the extracts by gel filtration and analyzed every other fraction in the HeLa nuclei assay for the ability to generate both $\approx 30-$ $50 \mathrm{~Kb}$ and oligonucleosomal DNA fragments. Figure $2 \mathrm{~A}$ is a typical absorbance profile obtained during this fractionation. A large peak of absorbance denotes the void volume of the column and absorbance tails off thereafter. Figure 2B shows that $\approx 30-50 \mathrm{~Kb}$ DNA-degrading activity was detected in fractions 33 through 73 , however, the peaks of this activity (measured by degradation of the greatest amount of total DNA to $\approx 30-50 \mathrm{~Kb}$ - shown by less smearing upward in the gel from this point) outside the void volume were in fractions $40-44(\approx 260 \mathrm{Kd})$ and $63-67(\approx 25 \mathrm{Kd})$. These peaks did 
not correspond with peaks of absorbance, indicating these activities are likely to be of low abundance (an expected characteristic for an enzyme). Analysis of low molecular weight DNA degrading activity from these same samples (Figure 2C) identified two peaks of activity, one (of very low activity) corresponding with the void volume and a second with an apparent molecular weight of $25 \mathrm{Kd}$. The $25 \mathrm{Kd}$ peak of internucleosomal cleavage activity coelutes exactly with a peak of $\approx 30-50 \mathrm{~Kb}$ DNA cleavage activity. Therefore, we chose to study further a pool composed of fractions 40-44, which produces $\approx 30-50 \mathrm{~Kb}$ DNA fragments exclusively, and a pool composed of fractions 63-67, which produced both $\approx 30-50 \mathrm{~Kb}$ and oligonucleosomal DNA fragments. The internucleosomal cleavage activity elutes with an identical molecular weight to the internucleosomal cleavage activity we

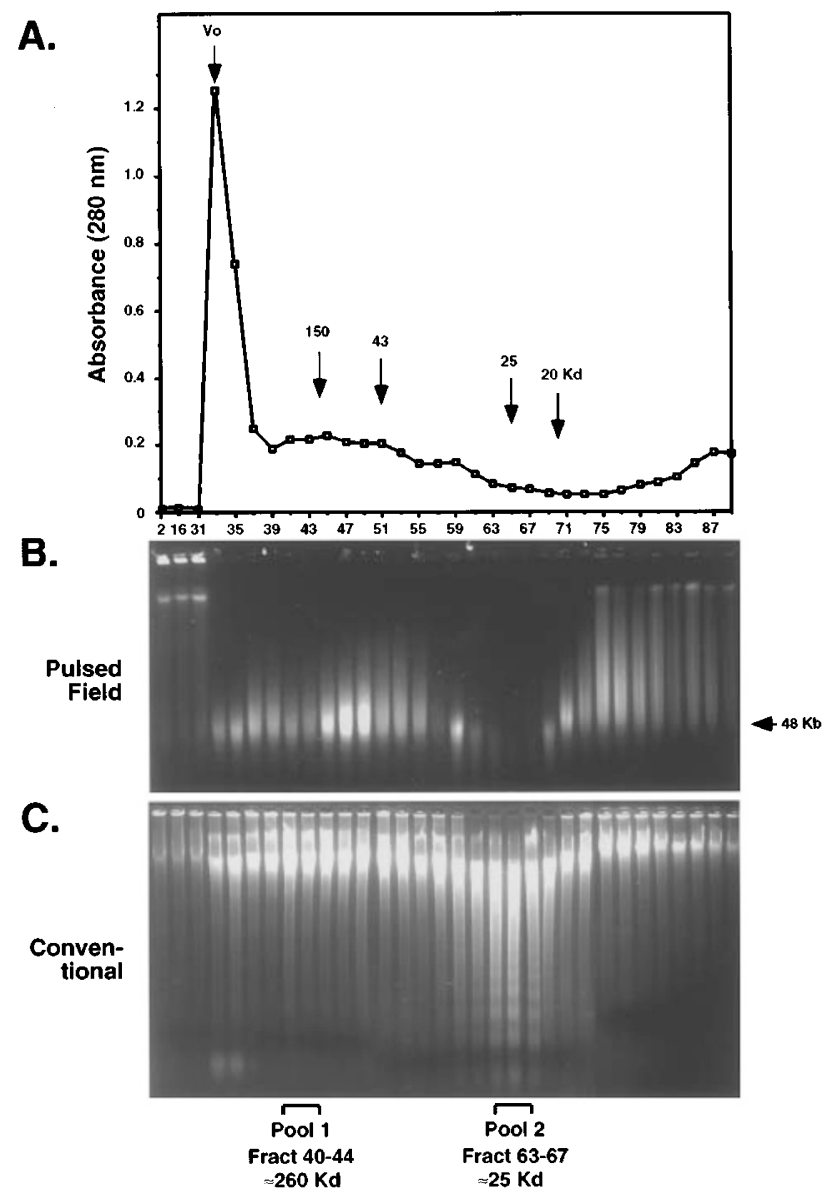

Figure 2 Gel filtration fractionation of thymocyte nuclear extract and analysis of DNA degrading activities. Nuclear extract $(18.9 \mathrm{mg})$ was applied to a Superose 12 column and every other fraction collected and frozen at $-70^{\circ} \mathrm{C}$ until analyzed. Fractions were thawed and $200 \mu \mathrm{l}$ was analyzed in the HeLa nuclei assay. (A) Profile depicting the absorbance at $280 \mathrm{~nm}$ of each tested fraction. (B) Pulsed field gel electrophoresis demonstrating the high molecular weight chromatin fragmentation patterns produced by each fraction tested in the HeLa nuclei assay. Fractions correspond to those marked above in the absorbance profile. (C) Conventional agarose gel electrophoresis depicting the low molecular weight chromatin fragmentation patterns produced by each fraction tested. The fractions constituting the studied pools (fractions 40-44 and fractions 63-67) are indicated on the bottom of this gel. Depicted is a representative experiment that has been repeated at least three times have previously identified in this system (Schwartzman and Cidlowski, 1991) and we believe it to be the same molecule. The molecular mass of this activity is very close to that of NUC18 which we have previously shown to be involved in $\approx 30-50 \mathrm{~Kb}$ DNA fragmentation during apoptosis (Montague et al, 1997). Western blot analysis of the protein present in all fractions using antisera we have generated against NUC 18 showed that this protein elutes in fractions 70-76 (data not shown). Thus, the internucleosomal cleavage activity we describe here is therefore not attributable to NUC 18 activity.

\section{Characterization of $\approx 30-50 \mathrm{~Kb}$ fragment and internucleosomal cleavage activities}

Figure 2 clearly shows the separation of two distinct activities in thymocyte nuclear extracts. To better define the relationship of these activities to previous characteristics attributed to apoptotic nucleases, we analyzed several characteristics of these activities and the DNA fragments they produce. DNA fragments produced during apoptosis have been shown to possess 3 '-OH termini which can be labeled with terminal deoxynucleotidyl transferase (Alnemri and Litwack, 1990). As shown in Figures $3 A$ and $B, \approx 30-50 \mathrm{~Kb}$ DNA fragments produced by both activity pools as well as the oligonucleosomal fragments produced by the internucleosomal cleavage activity efficiently label with terminal deoxynucleotidyl transferase, indicating that these activity pools produce DNA fragments consistent with those seen in vivo. Even with the greater sensitivity of this method of detection, no internucleosomal DNA degradation by the $\approx 30-50 \mathrm{~Kb}$ fragment cleavage activity was observed, confirming that this pool specifically and exclusively produces $\approx 30-50 \mathrm{~Kb}$ fragments.

Previous studies have shown that the nuclease activity responsible for internucleosomal cleavage is dependent on
A.

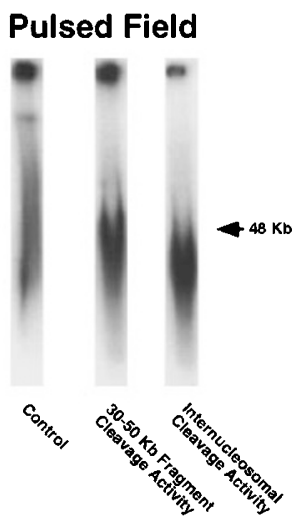

B.

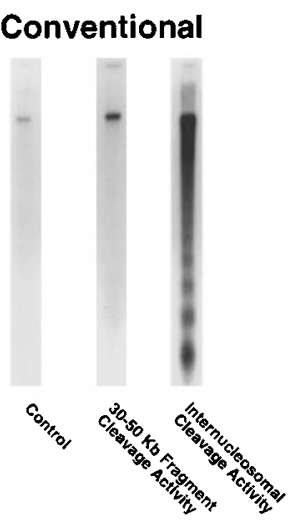

Figure 3 Endlabeling of DNA fragments produced by the $\approx 30-50 \mathrm{~Kb}$ fragment and internucleosomal cleavage activities, with terminal deoxynucleotidyl transferase. (A) Autoradiogram obtained from a pulsed field gel depicting the end labeled high molecular weight DNA fragments produced in the HeLa assay by the $\approx 30-50 \mathrm{~Kb}$ fragment (fractions $40-44$ ) and internucleosomal cleavage activities (fractions 63-67). (B) Autoradiogram obtained from a conventional agarose gel depicting the end labeled low molecular weight DNA fragments produced in the HeLa assay by the $\approx 30-$ $50 \mathrm{~Kb}$ fragment (fractions 40-44) and internucleosomal cleavage activities (fractions 63-67). Depicted are representative autoradiograms from a single experiment repeated at least two times 
both $\mathrm{Ca}^{2+}$ and $\mathrm{Mg}^{2+}$ for activity although it has been suggested that only $\mathrm{Mg}^{2+}$ is essential for producing $\approx 30-$ $50 \mathrm{~Kb}$ fragments (Montague et al, 1997; Sun and Cohen, 1994; Walker et al, 1994; reviewed in Hughes and Cidlowski, 1996). To assess the cation requirements of the $\approx 30-50 \mathrm{~Kb}$ fragment and the internucleosomal cleavage activity pools, we utilized EGTA and EDTA to chelate divalent cations. For example, to assess the effects of $\mathrm{Mg}^{2+}$ alone on the $\approx 30-50 \mathrm{~Kb}$ fragment cleavage activity, EGTA was added to the reaction to chelate the calcium, followed by addition of excess $\mathrm{MgCl}_{2}$. As shown in Figure 4 , very little $\approx 30-50 \mathrm{~Kb}$ DNA is produced by the $\approx 30-50 \mathrm{~Kb}$ fragment cleavage activity under these conditions $\left(\mathrm{Mg}^{2+}\right.$ only). Addition of excess $\mathrm{Ca}^{2+}$ completely restored the production of $\approx 30-50 \mathrm{~Kb}$ DNA fragmentation. As expected, no oligonucleosomal fragments were detected with this pool during any of these manipulations. When the internucleosomal cleavage activity was analyzed in this manner, neither the formation of oligonucleosomal fragments nor $\approx 30-50 \mathrm{~Kb}$ fragments were stimulated by $\mathrm{Mg}^{2+}$ alone but both activities were restored by addition of an excess of $\mathrm{Ca}^{2+}$. A similar experiment was performed to explore the effects of $\mathrm{Ca}^{2+}$ in this system. Both $\mathrm{Ca}^{2+}$ and $\mathrm{Mg}^{2+}$ were chelated with EDTA and then $\mathrm{Ca}^{2+}$ added in excess. As shown in Figure 4 , the $\approx 30-50 \mathrm{~Kb}$ fragment cleavage activity and internucleosomal cleavage activity possess minimal activity in the presence of only $\mathrm{Ca}^{2+}$, while addition of excess $\mathrm{Mg}^{2+}$ restored both activities. These results suggest that both pools of chromatin degradation activity require $\mathrm{Ca}^{2+}$ and $\mathrm{Mg}^{2+}$ for maximal activity.

Thiol-modifying compounds inhibit internucleosomal cleavage in other systems (Nikonova et al, 1993; Ribeiro and Carson, 1993). N-ethyl-maleimide alkylates free sulfhydral groups, making them unavailable for further reaction, while sodium tetrathionate oxidizes sulfhydrals to form disulfide bonds. As shown in Figure 5, incubation with $\mathrm{N}$-ethyl-maleimide (NEM) or sodium tetrathionate (NaTT) completely blocked DNA fragmentation by both pools, indicating that these activities are also dependent on free sulfhydral groups and/or disulfide bonds for activity.

We next explored the effects of aurintricarboxylic acid (ATC) and sodium chloride (both previously shown to suppress internucleosomal cleavage activity in crude nuclear extracts and other models of cell death and DNA fragmentation) on formation of $\approx 30-50 \mathrm{~Kb}$ and internucleosomal DNA fragments in our system (Nikonova et al, 1993; Ribeiro and Carson, 1993; Schwartzman and Cidlowski, 1993). As shown in Figure 5, the DNA binding inhibitor ATC blocked the $\approx 30-50 \mathrm{~Kb}$ DNA fragment production by both pools as well as the oligonucleosomal DNA fragmentation generated by the internucleosomal cleavage activity. Similarly, these activities were also blocked by levels of $\mathrm{NaCl}$ found in the extracellular environment, indicating they probably could not be active in necrotic cells in which the plasma membrane is compromised, and the $\mathrm{NaCl}$ levels equilibrate between the intracellular and extracellular compartments. Together these results show that the fractionated enzymes possess many characteristics ascribed to apoptotic nucleases.

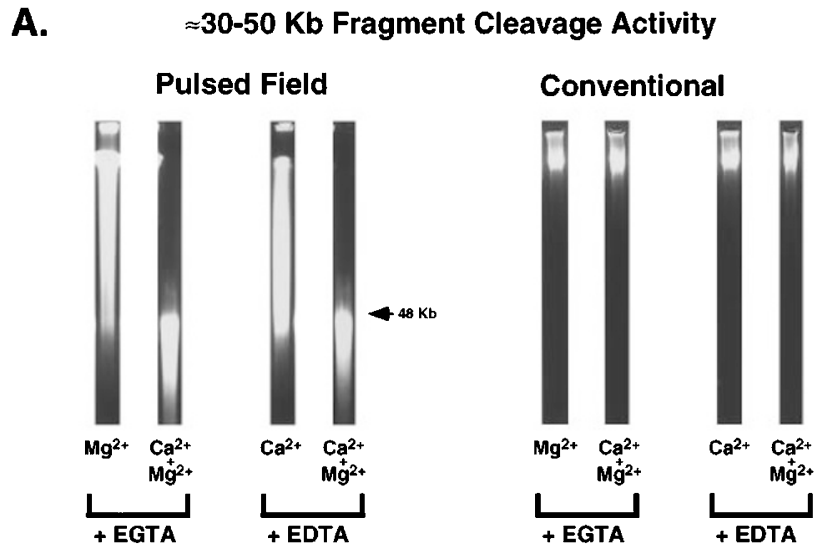

B. Internucleosomal Cleavage Activity

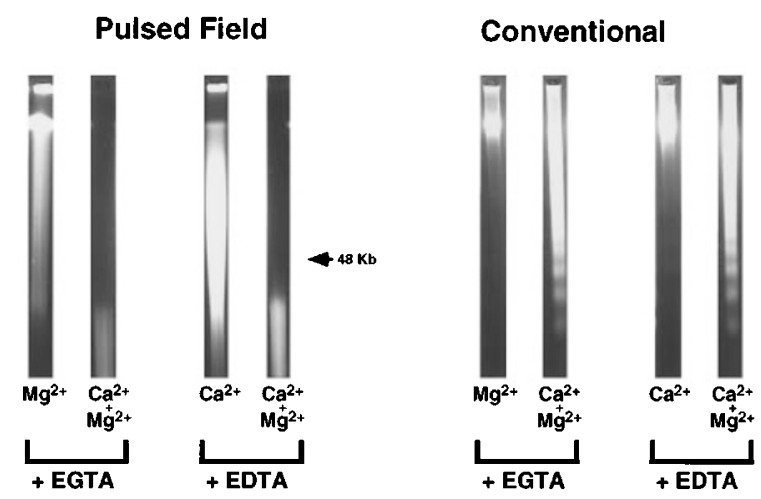

Figure 4 Cation dependency of the $\approx 30-50 \mathrm{~Kb}$ fragment and internucleosomal cleavage activities. To study $\mathrm{Mg}^{2+}$ dependency, the $\approx 30-50 \mathrm{~Kb}$ fragment and internucleosomal cleavage activities were briefly incubated (1 $\mathrm{min}$ ) with $2 \mathrm{mM} \mathrm{EGTA}$ prior to the addition of either $4 \mathrm{mM} \mathrm{MgCl}$, or $4 \mathrm{mM}$ $\mathrm{MgCl}_{2}$ and $4 \mathrm{mM} \mathrm{CaCl}$. To study $\mathrm{Ca}^{2+}$ dependency, the $\approx 30-50 \mathrm{~Kb}$ fragment and internucleosomal cleavage activities were briefly incubated with $1 \mathrm{mM}$ EDTA prior to the addition of $5 \mathrm{mM} \mathrm{CaCl}_{2}$, or $5 \mathrm{mM} \mathrm{CaCl}_{2}$ and $2 \mathrm{mM}$ $\mathrm{MgCl}_{2}$. (A) Pulsed field electrophoretic analysis of the high molecular weight chromatin fragments produced by the $\approx 30-50 \mathrm{~Kb}$ fragment and internucleosomal cleavage activities under the indicated experimental conditions. (B) Conventional agarose gel electrophoretic analysis of the low molecular weight chromatin fragments produced by the $\approx 30-50 \mathrm{~Kb}$ fragment and internucleosomal cleavage activities under the indicated experimental conditions. Depicted are representative gels from a single experiment repeated at least three times

\section{Inhibition of $\approx 30-50 \mathrm{~Kb}$ fragment and internucleosomal cleavage activities by non- caspase protease inhibitors}

The importance of proteolysis in an apoptotic cell, upstream of DNA fragmentation, is now firmly established. To assess the potential involvement of a protease-dependent step in the generation of $\approx 30-50 \mathrm{~Kb}$ and internucleosomal DNA fragments, these activities were assayed in the presence of several different protease inhibitors. The results, shown in Figure 6, demonstrate that both activity pools were inhibited by the serine protease inhibitors TPCK and TLCK whereas another serine protease inhibitor, diisopropylfluorophosphate 
A.

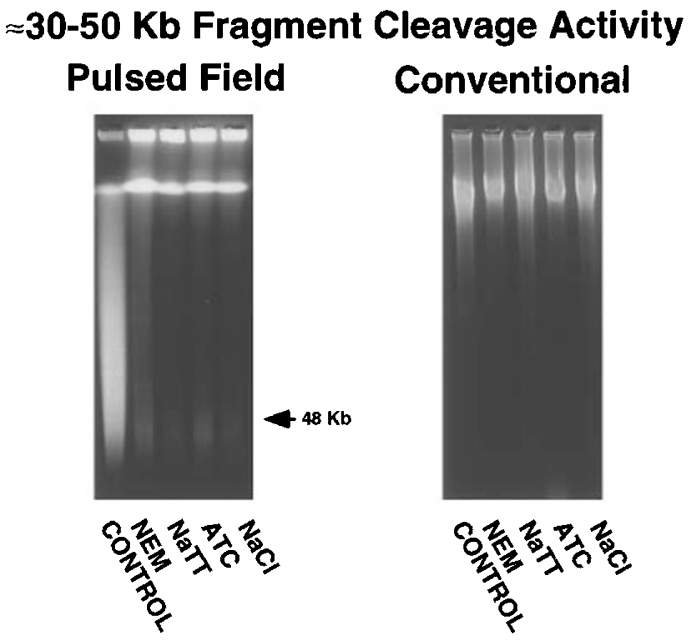

B.

\section{Internucleosomal Cleavage Activity Pulsed Field Conventional}
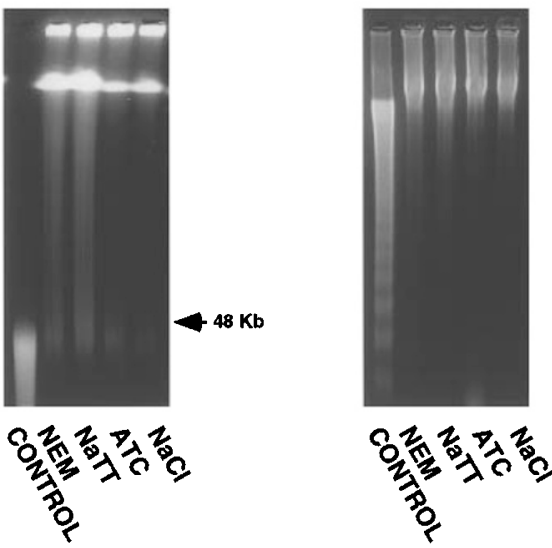

Figure 5 Effects of nuclease inhibitors on the $\approx 30-50 \mathrm{~Kb}$ fragment and internucleosomal cleavage activities. The $\approx 30-50 \mathrm{~Kb}$ fragment and internucleosomal cleavage activities were incubated in the HeLa nuclei assay in the presence of $100 \mu \mathrm{M} \mathrm{NEM}, 50 \mu \mathrm{M} \mathrm{NaTT}, 10 \mathrm{mM}$ ATC or $100 \mathrm{mM}$ $\mathrm{NaCl}$. (A) Pulsed field electrophoretic analysis of the high molecular weight chromatin fragments produced by the $\approx 30-50 \mathrm{~Kb}$ fragment and internucleosomal cleavage activities in the presence or absence of the indicated inhibitors. (B) Conventional agarose gel electrophoretic analysis of the low molecular weight chromatin fragments produced by the $\approx 30-50 \mathrm{~Kb}$ fragment and internucleosomal cleavage activities in the presence or absence of the indicated inhibitors. Depicted are representative gels from a single experiment repeated at least three times

(DFP), and the calpain inhibitors, Calpain Inhibitor I and Calpain Inhibitor II, had no effect. Therefore, we next examined the effects of caspase inhibitors on the DNA degradation produced by these pools. As shown in Figure 7, neither the caspase-1 selective inhibitor YVAD-ald, the caspase-3 selective inhibitor DEVD-ald, nor the general caspase inhibitor Z-VAD-fmk had any effect on either activity pool, although these inhibitors effectively suppressed
A.

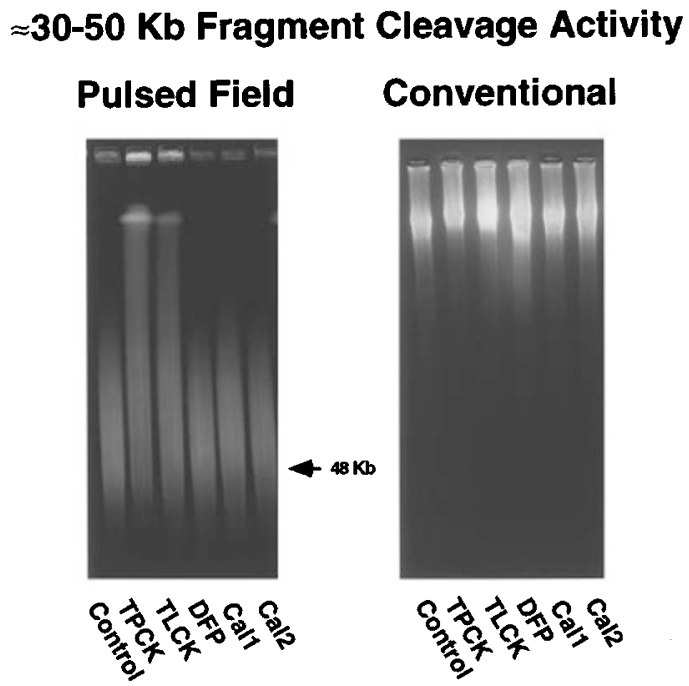

B.

\section{Internucleosomal Cleavage Activity \\ Conventional}
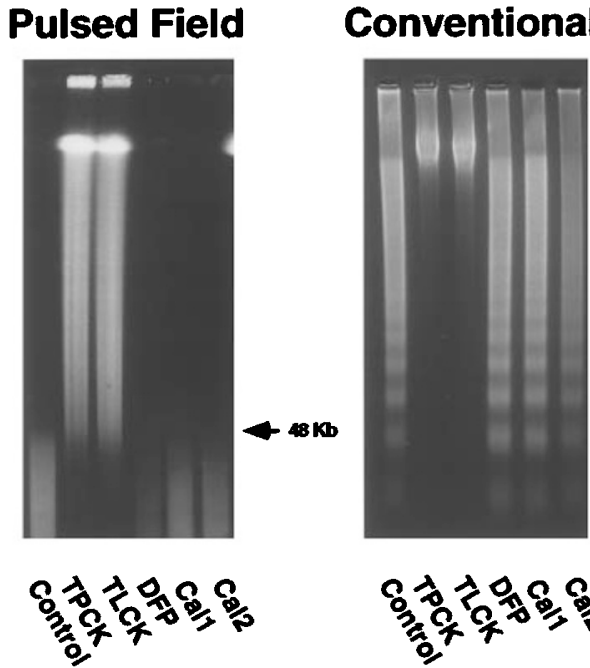

Figure 6 Effects of protease inhibitors on the $\approx 30-50 \mathrm{~Kb}$ fragment and internucleosomal cleavage activities. The $\approx 30-50 \mathrm{~Kb}$ fragment and internucleosomal cleavage activities were incubated in the HeLa nuclei assay in the presence or absence of $200 \mu \mathrm{M}$ TPCK, $1 \mathrm{mM}$ TLCK, $100 \mu \mathrm{M}$ DFP, $100 \mu \mathrm{M}$ Cal1 or $100 \mu \mathrm{M} \mathrm{Cal2} \mathrm{(A)} \mathrm{Pulsed} \mathrm{field} \mathrm{electrophoretic} \mathrm{analysis} \mathrm{of}$ the high molecular weight chromatin fragments produced by the $\approx 30-50 \mathrm{~Kb}$ fragment and internucleosomal cleavage activities in the presence or absence of the indicated inhibitors. (B) Conventional agarose gel electrophoretic analysis of the low molecular weight chromatin fragments produced by the $\approx 3050 \mathrm{~Kb}$ fragment and internucleosomal cleavage activities in the presence or absence of the indicated inhibitors. Depicted are representative gels from a single experiment repeated at least three times

caspase activity in other enzymatic assays (unpublished data). Thus, these results suggest that the activities in the fractionated extracts are caspase-independent. 


\section{$\approx 30-50 \mathrm{~Kb}$ fragment and internucleosomal cleavage activities possess inherent nuclease activity that is not affected by protease inhibitors}

The data thus far suggest that both the $\approx 30-50 \mathrm{~Kb}$ fragment and internucleosomal cleavage activity pools contain both protease and nuclease activities. However, the mechanisms by which these activities interact remains unclear. For example, proteolytic activity may directly activate a latent thymocyte or HeLa nuclease or the protease(s) may attack

A.

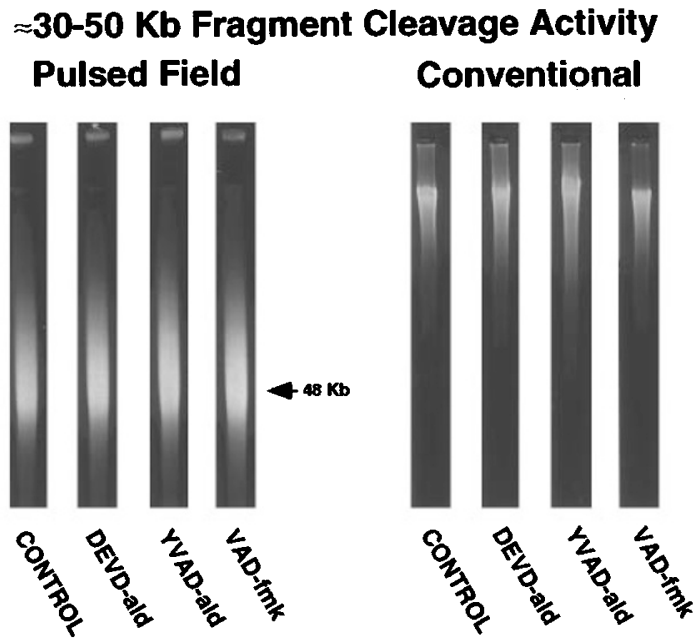

B.
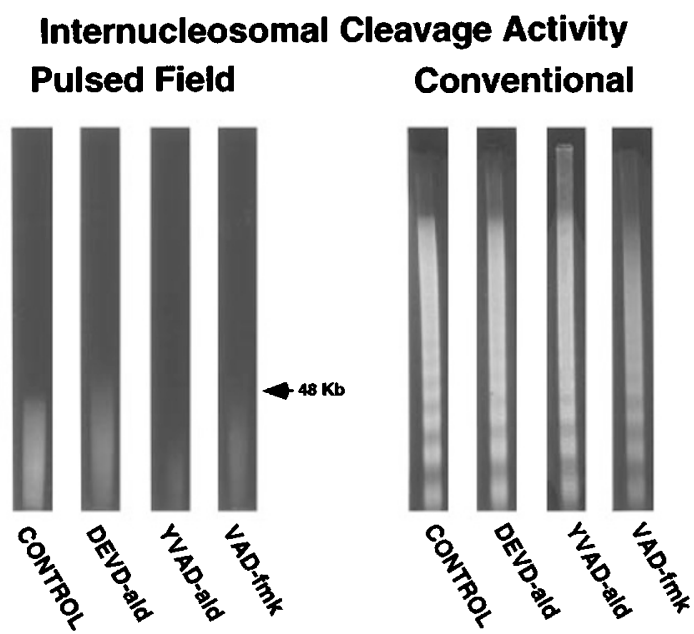

Figure 7 Effects of caspase inhibitors on the $\approx 30-50 \mathrm{~Kb}$ fragment and internucleosomal cleavage activities. The $\approx 30-50 \mathrm{~Kb}$ fragment and internucleosomal cleavage activities were incubated in the HeLa nuclei assay in the presence or absence of $100 \mu \mathrm{M}$ DEVD-ald, YVAD-ald, or VAD fmk. (A) Pulsed field electrophoretic analysis of the high molecular weight chromatin fragments produced by the $\approx 30-50 \mathrm{~Kb}$ fragment and internucleosomal cleavage activities in the presence or absence of the indicated inhibitors. (B) Conventional agarose gel electrophoretic analysis of the low molecular weight chromatin fragments produced by the $\approx 30-50 \mathrm{~Kb}$ fragment and internucleosomal cleavage activities in the presence or absence of the indicated inhibitors. Depicted are representative gels from a single experiment repeated at least three times the chromatin directly, making it more susceptible to nucleolytic cleavage. To assess these possibilities we examined the nuclease activity of each pool on a substrate of minimal chromatin structure (naked, linearized pUC18 plasmid). As shown in Figure 8 , both the $\approx 30-50 \mathrm{~Kb}$ fragment and internucleosomal cleavage pools were able to degrade plasmid efficiently, indicating that these fractions possess inherent nuclease activity. Interestingly, the fragmented DNA appeared as specific bands rather than a smear, suggesting that these nucleases may cleave at sequence or structure-dependent sites. Importantly, the protease inhibitors examined did not suppress plasmid degradation by either pool, suggesting that the effects of these compounds on the HeLa nuclei assay are through a direct inhibition of a protease and are not mediated through a non-specific inhibition of nuclease activity, and that the protease activity of each pool is most likely altering chromatin structure. An alternate interpretation is that several nucleases are present in the fractions, and that different ones are responsible for degradation of linear plasmid and chromosomal DNA.

To insure that TPCK and TLCK are not functioning in these experiments by altering the HeLa chromatin structure in such a manner as to make it completely inaccessible to nuclease cleavage, we analyzed the effect of purified micrococcal nuclease and DNase I in the HeLa nuclei assay. As shown in Figure 9, both micrococcal nuclease and DNase I generate $\approx 30-50 \mathrm{~Kb}$ fragments in the HeLa chromatin. Micrococcal nuclease produced oligonucleoso-
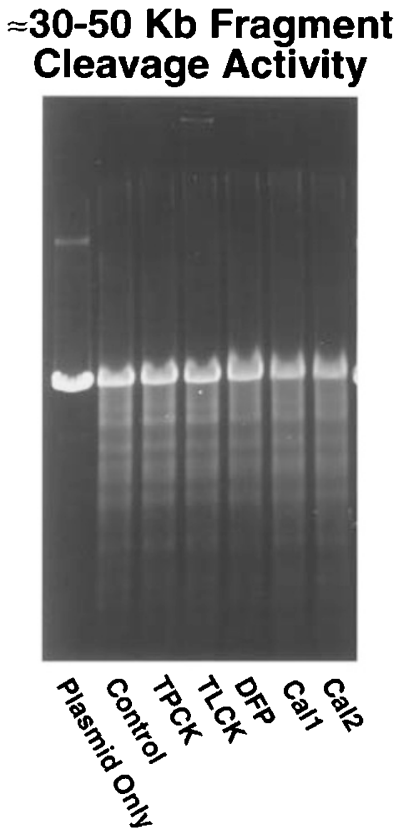
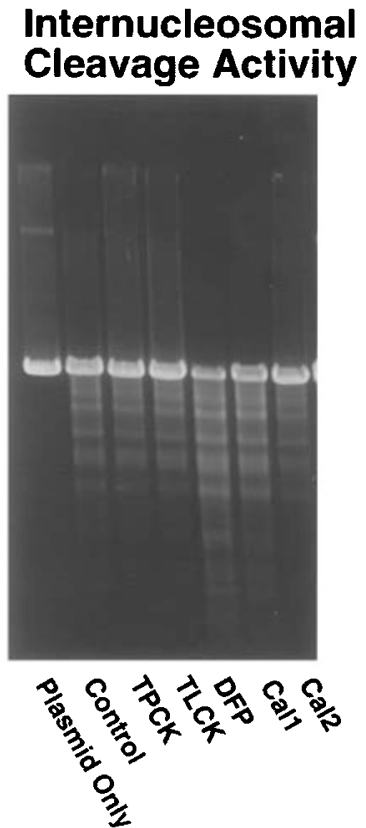

Figure 8 Effects of protease inhibitors on the nuclease activity of the $\approx 30-$ $50 \mathrm{~Kb}$ fragment and internucleosomal cleavage activities. The $\approx 30-50 \mathrm{~Kb}$ fragment and internucleosomal cleavage activities were incubated for $5 \mathrm{~h}$ $\left(37^{\circ} \mathrm{C}\right)$ with naked linearized plasmid, as described in Materials and Methods, in the presence or absence of $200 \mu \mathrm{M} \mathrm{TPCK}, 1 \mathrm{mM}$ TLCK, $100 \mu \mathrm{M} \mathrm{DFP}, 100 \mu \mathrm{M}$ Cal1, or $100 \mu \mathrm{M}$ Cal2. Following incubation, the DNA degradation patterns were analyzed by conventional agarose gel electrophoresis. Depicted is a representative agarose gel from a single experiment repeated at least three times 
A.

\section{Micrococcal Nuclease Pulsed Field Conventional}
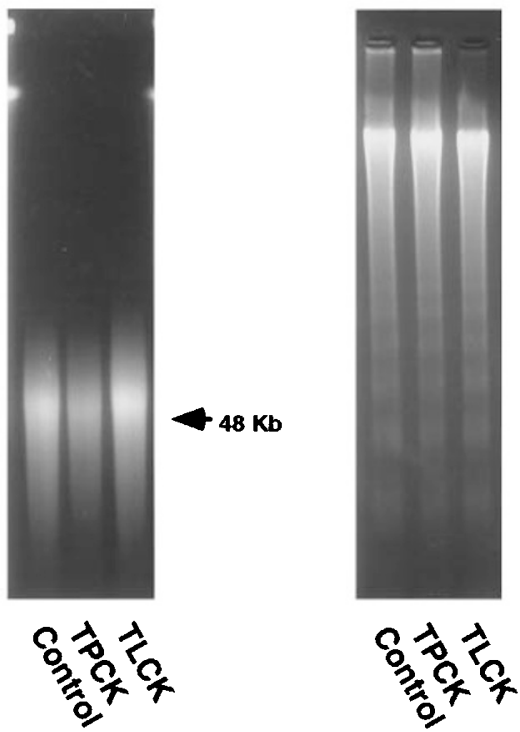

B.
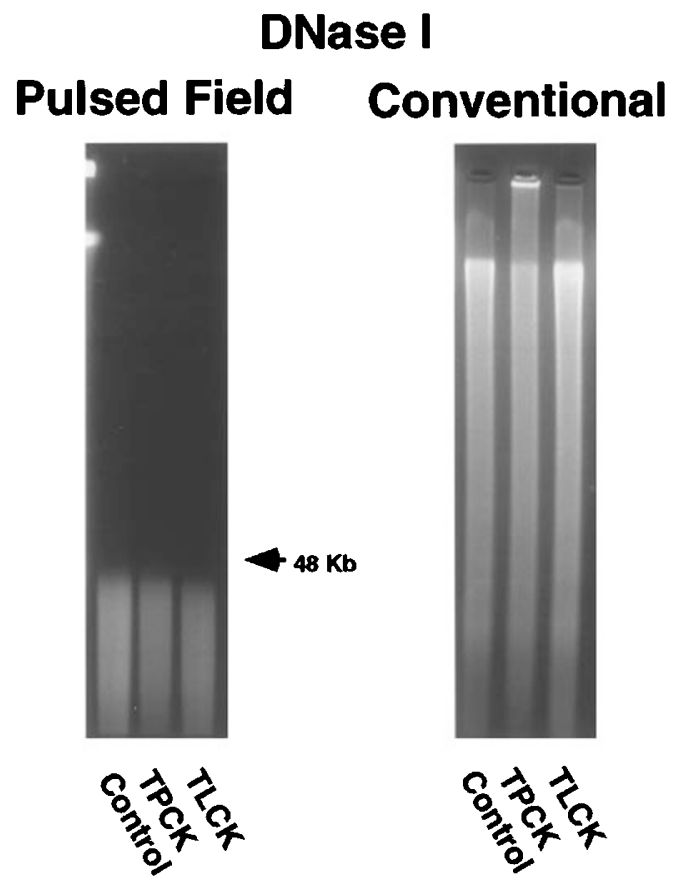

Figure 9 Effects of TPCK and TLCK on the HeLa chromatin degradation by micrococcal nuclease (MN) and DNase I. MN (1 ng) and DNase I (50 ng) were incubated in the HeLa nuclei assay in the presence or absence of $200 \mu \mathrm{M}$ TPCK or $1 \mathrm{mM}$ TLCK. (A) Pulsed field electrophoretic analysis of the high molecular weight chromatin fragments produced by MN and DNase I in the presence or absence of the indicated inhibitors. (B) Conventional agarose gel electrophoretic analysis of the low molecular weight chromatin fragments produced by MN and DNase I in the presence or absence of the indicated inhibitors. Depicted are representative gels from a single experiment repeated at least three times mal fragments on a conventional agarose electrophoretic gel while DNase I generated a smear (due to random cleavage). TPCK or TLCK had no effect on the activity of either enzyme, suggesting that the chromatin remains accessible in the presence of these compounds. Moreover, the results imply that the apoptotic nuclease(s) in these pools have a more stringent steric requirement than micrococcal nuclease or DNase I (i.e. requires DNA to be in a more relaxed configuration for cleavage, likely a result of the protease activity in these pools).

\section{Discussion}

In the present study we have explored the nature and specificity of the enzymes associated with chromatin degradation during apoptosis. We have identified two separate activities. One of high molecular weight $(\approx 260 \mathrm{Kd})$ exclusively produces $\approx 30-50 \mathrm{~Kb}$ fragments and a second $(\approx 25 \mathrm{Kd}$ ) produces both $\approx 30-50 \mathrm{~Kb}$ and oligonucleosomal fragments (internucleosomal cleavage activity). The internucleosomal cleavage activity has previously been identified by our laboratory based on its ability to produce internucleosomal fragments (Schwartzman and Cidlowski, 1991; 1993), although the $\approx 30-50 \mathrm{~Kb}$ fragment-generating activity of this pool has not been described previously. It is unclear, at present, whether both activitites in the internucleosomal cleavage pool arise from the same enzyme or from separate constituents. However, given the identical molecular weight of both activities, and the observation that a single enzyme (micrococcal nuclease) can generate both $\approx 30-50 \mathrm{~Kb}$ and oligonucleosomal fragments (Figure 9 and Hughes and Cidlowski, 1997), it is possible that both activities are mediated by the same protein. Characterization revealed that both the $\approx 30-50 \mathrm{~Kb}$ fragment and internucleosomal cleavage activities require $\mathrm{Ca}^{2+}$ and $\mathrm{Mg}^{2+}$ for optimal activity. Previous studies have suggested that the nuclease producing $\approx 30-50 \mathrm{~Kb}$ fragments only requires $\mathrm{Mg}^{2+}$ (Sun and Cohen, 1994; Walker et al, 1994; reviewed in Hughes and Cidlowski, 1996). Our results do not conflict with these studies, although they suggest that both $\mathrm{Ca}^{2+}$ and $\mathrm{Mg}^{2+}$ are required for appropriate proteolytic preparation of the chromatin for $\approx 30-$ $50 \mathrm{~Kb}$ fragmentation. We determined by endlabeling with terminal deoxynucleotidyl transferase that the $\approx 30-50 \mathrm{~Kb}$ and oligonucleosomal DNA fragments generated in our system possess $3^{\prime}-\mathrm{OH}$ termini, a characteristic of apoptotic fragments (Alnemri and Litwack, 1990). The high sensitivity of endlabeling confirmed that the $\approx 30-50 \mathrm{~Kb}$ fragment cleavage activity did not produce any low molecular weight DNA fragments. Both activity pools are sensitive to thiolmodifying chemicals indicating the importance of free sulphydral groups/disulfide bonds for their activity. The $\approx 30-50 \mathrm{~Kb}$ and internucleosomal DNA cleavage activities are inhibited by ATC which has been used in numerous studies of apoptotic nucleases based on its ability to inhibit nuclease activity by blocking DNA binding as well as interacting directly with nucleases (Hallick et al, 1977; McConkey et al, 1989). Both the $\approx 30-50 \mathrm{~Kb}$ fragment and internucleosomal DNA cleavage activities were also inhibited by levels of $\mathrm{Na}^{+}$previously shown to suppress $\mathrm{Ca}^{2+}$-induced DNA fragmentation in isolated CTLL-2 nuclei (Nieto and 
Lopez-Rivas, 1989). We have also shown that this level of $\mathrm{Na}^{+}$suppresses the internucleosomal DNA cleavage activity in the crude extract (Schwartzman and Cidlowski, 1993). Since the levels of $\mathrm{Na}^{+}$used are similar to that found in the extracellular environment, the results suggest that the nucleases could not be active during necrosis where the plasma membrane is compromised and intracellular $\mathrm{Na}^{+}$ levels equilibrate with the extracellular environment.

The nucleolytic activities we have identified have molecular masses of approximately 260 and $25 \mathrm{kDa}$ as determined by gel filtration chromatography. Other investigators have suggested that the nucleases responsible for internucleosomal and $\approx 30-50 \mathrm{~Kb}$ DNA cleavage may be independent, but only one group has separated such activities (Pandey et al, 1994). These investigators demonstrated that chromatin in nuclei washed in low ionic strength buffer was cleaved into $50 \mathrm{~Kb}$ fragments, but was not cleaved internucleosomally. Although the internucleosomal DNA cleavage activity we describe here is also capable of eliciting chromatin cleavage into $\approx 30-50 \mathrm{~Kb}$ fragments, we are the first to describe the molecular mass for an activity that exclusively produces such large chromatin fragments. We have been unable to locate any enzyme in the literature that possesses a similar molecular weight and biochemical characteristics as the $\approx 30-50 \mathrm{~Kb}$ cleavage activity identified in this study, suggesting it is likely a novel enzyme, or a multimeric complex of lower molecular weight subunits of an enzyme.

Little consensus exists as to the nuclease(s) responsible for internucleosomal DNA cleavage. The molecular weights of CAD (40 Kd), nuc-40, ILCME (45-49 kDa), nuc-58 (58 kDa) and a $97 \mathrm{kDa}$ nuclease implicated in this cleavage are too high to be identical to our activity (although molecular weight may differ substantially in SDS-PAGE versus size-exclusion chromatography). Additional nucleases that have been implicated in this type of DNA cleavage and have molecular weights that might be consistent with the activity we describe include DNases I, II, and $\gamma, \mathrm{NUC}-18$, and a $25 \mathrm{kDa}$ nuclease previously identified in this laboratory. Unlike the internucleosomal DNA cleavage activity described in this manuscript, DNase I is not inhibited by ATC while DNase II is not active at neutral pH (Barry and Eastman, 1993; Peitsch et al, 1994). NUC 18 and a $25 \mathrm{kDa}$ nuclease were identified in this laboratory and have been implicated in apoptosis. We were able to demonstrate by Western blot that NUC 18 does not copurify with the activity described in this manuscript (data not shown). It is possible, however, that the internucleosomal cleavage activity may be similar to the previously identified $25 \mathrm{kDa}$ nuclease, or to DNase $\gamma$ (31 kDa) since both of these nucleases require $\mathrm{Mg}^{2+}$ and $\mathrm{Ca}^{2+}$ for activity, are inhibited by ATC, and form 3' $\mathrm{OH}$ DNA termini.

When we investigated a potential role for proteases in these activities we found that both the $\approx 30-50 \mathrm{~Kb}$ fragment and internucleosomal activities were inhibited by the serine protease inhibitors TPCK and TLCK. TPCK and TLCK also inhibit certain cysteine proteases (Kaufmann et al, 1993), including caspases (Patel et al, 1996). The caspase-1 selective inhibitor DEVD-ald, the caspase-3 selective inhibitor YVAD-ald and the general caspase inhibitor Z-VAD-fmk had no effect on these activities, indicating a non-caspase protease was involved. Both the $\approx 30-50 \mathrm{~Kb}$ and internucleosomal DNA cleavage activity pools were shown to possess inherent nuclease activity that was not effected by protease inhibitors. These results suggest that during apoptosis proteolytic disruption of the normally tight packing of the chromatin is necessary to expose the relevant sites to subsequent nuclease cleavage. The purified nucleases micrococcal nuclease and DNase I were not affected by TPCK and TLCK suggesting the apoptotic nucleases have a high level of steric requirements (i.e. require very open chromatin) and that both protease and nuclease activities are contributed by the pooled thymocyte fractions.

Several studies have also identified non-caspase proteolytic activities that are important during apoptosis. For example, Wright et al (1994) purified a 24-kD protease from U937 lymphoma cells which triggered internucleosomal DNA fragmentation in U937 nuclei. This activity has a molecular weight similar to our internucleosomal DNA degradation pool although the $24 \mathrm{Kd}$ activity was not inhibited by TLCK. Another non-caspase protease implicated in apoptosis is calpain (Squier and Cohen, 1997) and inhibitors of this enzyme have been shown to prevent the glucocorticoid-induced death of thymocytes. However, in the present experiments, two different calpain inhibitors failed to inhibit protease activity, suggesting that calpain must function upstream in the DEX-induced thymocyte death pathway.

The present results clearly implicate separate noncaspase proteases in altering chromatin structure to independently facilitate oligonucleosomal and $\approx 30-50 \mathrm{~Kb}$ DNA fragmentation. The origin of the protease activity (extract or endogenous to the HeLa nuclei) in our experiments is not known, however, the importance of alterations in chromatin structure for DEX-induced thymocyte apoptosis has been documented by Weaver et al (1996) who showed that nuclear lamin B cleavage was essential to proper chromatin destruction. Their study did not attempt to identify the protease(s) involved. The exact targets of $\approx 30-50 \mathrm{~Kb}$ fragment and internucleosomal activities are presently unknown, but the presence of nuclear proteases which can alter the nuclear and chromatin structure has been previously established. One example is the $\mathrm{Ca}^{2+}$-regulated serine protease which associates with the nuclear scaffold (Clawson et al, 1992). While the nuclear scaffold would seem a logical target for the protease activities in our pools, the previously identified nuclear scaffold protease is inhibited by DFP in contrast to our activities. Ongoing studies are aimed at determining the substrate specificity of $\approx 30-50 \mathrm{~Kb}$ fragment and internucleosomal DNA cleavage activities.

In conclusion, we have utilized gel filtration chromatography to identify two separate activities (from the nucleus of glucocorticoid-treated apoptotic thymocytes) which stimulate chromatin breakdown in isolated HeLa nuclei. The $\approx 30-50 \mathrm{~Kb}$ fragment cleavage activity pool is of high molecular weight $(\approx 260 \mathrm{Kd})$ and exclusively facilitates the production of $\approx 30-50 \mathrm{~Kb}$ chromatin fragments, whereas the internucleosomal cleavage activity pool is $\approx 25 \mathrm{Kd}$ and 
produces both $\approx 30-50 \mathrm{~Kb}$ as well as the classic oligonucleosomal apoptotic fragments. Both activities are dependent on $\mathrm{Ca}^{2+}$ and $\mathrm{Mg}^{2+}$ for maximal activity, produce DNA fragments with $3^{\prime}-\mathrm{OH}$ termini, are sensitive to thiolmodifying reagents and are inhibited by ATC and $\mathrm{NaCl}$. These activities were also inhibited by select serine protease inhibitors but not by calpain inhibitors or caspase inhibitors. Both the $\approx 30-50 \mathrm{~Kb}$ fragment and internucleosomal cleavage activities contain endogenous nuclease activity, indicating that specific proteolysis exposes sites in chromatin to nucleolytic degradation. The separation of these two activities suggests that during apoptosis separate proteases modify the chromatin to prepare it for each type of DNA degradation.

\section{Materials and Methods}

\section{Reagents}

Joklik's minimum essential medium was received from Flow Laboratories (McLean, VA) while fetal calf serum and calf serum was obtained from Irvine Scientific (Santa Ana, CA). Phenol:chloroform:isoamyl alcohol was obtained from Gibco BRL:Life Technologies (Gaithersburg, MD) whereas Superose 12 gel filtration media was received from Pharmacia (Uppsala, Sweden). Dexamethasone was purchased from Steraloids (Wilton NH). Tosyl-L-phenylalanine chloromethyl ketone (TPCK), N $\alpha$-p-tosyl-L-lysine chloromethyl ketone (TLCK), diisopropyl fluorophosphate (DFP), N-ethyl-maleimide (NEM), sodium tetrathionate (NaTT) and aurintricarboxylic acid (ATC) and DNase I (1900 Units/mg) were obtained from Sigma Chemical Corp. (St. Louis, MO). Calpain Inhibitor I (Cal1) and Calpain Inhibitor II (Cal2) were purchased from Calbiochem (La Jolla, CA). Sodium chloride $(\mathrm{NaCl})$ from Mallinckrodt Baker, Inc. (Phillipsburg, NJ). AcAsp-Glu-Val-Asp-aldehyde (DEVD-ald) and Ac-Tyr-Val-Ala-Asp-aldehyde (YVAD-ald) were purchased from Bachem (King of Prussia, PA) while Z-Val-Ala-Asp-fluoromethyl ketone (VAD-fmk) was received from Kamiya Biomedical Co. (Seattle, WA). Micrococcal nuclease $(16,322$ Units/mg) was obtained from Worthington Biochemical Corporation (Freehold, NJ) while terminal deoxynucleotidyl transferase, dideoxyATP, and ultrapure glycogen were purchased from Boehringer Mannheim (Indianapolis, IN). [ $\alpha^{32} \mathrm{P}$-dideoxyATP] was received from ICN (Costa Mesa, CA).

\section{Animals \\ Adult male Sprague-Dawley rats of approximately 150-300 g were used in all experiments. The animals were bilaterally adrenalecto- mized by the provider at least 5 days prior to use and maintained under controlled conditions of temperature $\left(25^{\circ} \mathrm{C}\right)$ and lighting (lights on $0600-1800 \mathrm{~h}$ ) and allowed free access to food and saline. All experimental protocols were approved by the animal review committee at the institute and were performed in accordance with the regulations set forth in the 'Guide for the Care and Use of Laboratory Animals' published by the Public Health Service.}

\section{Preparation of thymocyte nuclear extract}

Thymocyte nuclear extract was prepared as previously described (Hughes and Cidlowski, 1996). Briefly, rats were injected i.p. $4 \mathrm{~h}$ prior to sacrifice with dexamethasone ( $5 \mathrm{mg} / \mathrm{Kg}$ body weight) suspended by sonication in phosphate buffered saline. Previously we have determined that this results in $\approx 50 \%$ degradation of the thymocyte genome while maintaining a high cellular viability $(\approx 98 \%)$ (Compton and Cidlowski, 1986). Following the $4 \mathrm{~h}$ in vivo incubation period, rats were sacrificed, the thymus removed and thymocytes harvested by gentle homogenization in a loose fitting Kontes no. 22 glass/glass homogenizer (Kontes Co., Vineland, NJ) on ice. Suspensions were filtered (202 $\mu \mathrm{m}$ Nitex mesh; Tetko, New York, NY), washed once in ice-cold PBS and the plasma membranes lysed (10 $\mathrm{mM} \mathrm{MgCl}_{2}, 0.25 \%$ Nonidet P-40). Nuclei were pelleted, resuspended in extraction buffer (300 mM NaCl, 1 mM EDTA, $20 \mathrm{mM}$ Tris (pH 7.4); $0.5 \mathrm{ml} /$ thymus) and rotated at $4{ }^{\circ} \mathrm{C}$ for $1 \mathrm{~h}$. Extracts were then cleared of debris and endogenous chromatin by ultracentrifugation at $165000 \times g$ for $1 \mathrm{~h}$ at $4^{\circ} \mathrm{C}$. Supernates were harvested and an aliquot removed and stored at $-70^{\circ} \mathrm{C}$. The remainder was applied to the gel filtration column. Protein concentrations were determined by the method of Bradford (1976).

\section{Gel filtration chromatography}

Extracts (18-22 $\mathrm{mg}$ ) were fractionated by size exclusion chromatography through Superose 12 prep grade gel filtration media (Pharmacia Biotech; Piscataway, $\mathrm{NJ}$ ) at $4^{\circ} \mathrm{C}$. The media was packed in an HR 16/50 column (Pharmacia Biotech; Piscataway, NJ) to a height of $49.2 \mathrm{~cm}$ following instructions in the package insert and equilibrated with chromatography buffer $(0.1 \mathrm{mM}$ phenylmethylsulfonylfluoride, $20 \mathrm{mM} \mathrm{NaCl}, 1 \mathrm{mM}$ EDTA, $20 \mathrm{mM}$ Tris, $\mathrm{pH}$ 7.4). The column was then calibrated using $2 \mathrm{mg}$ of catalase ( $232 \mathrm{Kd}$ ), yeast alcohol dehydrogenase $(150 \mathrm{Kd})$, ovalbumin $(43 \mathrm{Kd})$, chymotrypsinogen $\mathrm{A}(25 \mathrm{Kd})$ and trypsin inhibitor $(20 \mathrm{Kd})$. Extracts were loaded onto the column in a total volume of $2 \mathrm{ml}$ using a Waters 650E Advanced Protein Purification System (Millipore Corp., Milford, MA) that controlled flow at $1 \mathrm{ml} / \mathrm{min}$ and monitored throughput by UV absorbance at $280 \mathrm{~nm}$. Two $\mathrm{ml}$ fractions were collected and assayed for nuclease activity.

\section{HeLa nuclei assay}

The HeLa nuclei assay was performed as previously described (Hughes and Cidlowski, 1997; Schwartzman and Cidlowski, 1991; 1993). Briefly, HeLa cells were maintained $\left(37^{\circ} \mathrm{C}\right)$ in suspension between $1 \times 10^{5}$ and $7 \times 10^{5}$ cells $/ \mathrm{ml}$ in Joklik's minimum essential medium supplemented with $2 \%$ fetal calf serum, $2 \%$ calf serum, $2 \mathrm{mM}$ glutamine, $75 \mathrm{U} / \mathrm{ml}$ penicillin and $50 \mathrm{U} / \mathrm{ml}$ streptomycin sulfate. Prior to assay, cells were counted, pelleted, and the plasma membranes lysed by resuspension in $10 \mathrm{mM} \mathrm{MgCl}_{2}, 0.25 \%$ Nonidet P-40. Nuclei were

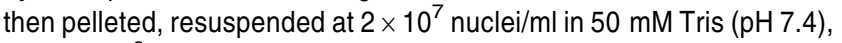
and $2 \times 10^{6}$ nuclei were added to microcentrifuge tubes containing

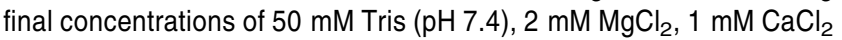
and experimental treatments in a total volume of $400 \mu$. Tubes were then rotated for $5 \mathrm{~h}$ at room temperature prior to harvest.

For pulsed field analysis, $200 \mu \mathrm{l}$ of the reaction was removed and mixed with $200 \mu \mathrm{l}$ of prewarmed $\left(37^{\circ} \mathrm{C}\right) 1 \%$ Incert agarose (FMC BioProducts, Rockland, ME). The mixture was then transferred to a mold $\left(0.5 \mathrm{~cm}^{2}\right)$ and solidified at $4{ }^{\circ} \mathrm{C}$ for $5 \mathrm{~min}$. Plugs were then extruded into $10 \mathrm{ml}$ of $100 \mathrm{mM}$ EDTA, $1 \%$ (w/v) N-lauroyl-sarcosine and incubated overnight $\left(37^{\circ} \mathrm{C}\right)$. Subsequently plugs were placed in $1 \mathrm{ml}$ of the same buffer containing proteinase $\mathrm{K}(100 \mu \mathrm{g})$ and incubated at $50^{\circ} \mathrm{C}$ for a minimum of $16 \mathrm{~h}$. Plugs were then stored $\left(4^{\circ} \mathrm{C}\right)$ in this buffer until used.

For conventional electrophoresis, EDTA, $\mathrm{NaCl}$ and sodium dodecyl sulfate (final concentrations of $25 \mathrm{mM}, 540 \mathrm{mM}$ and $0.5 \%$, respectively) were added to the remaining sample. TE buffer $(10 \mathrm{mM}$ Tris $(\mathrm{pH}$ 7.4), $1 \mathrm{mM}$ EDTA) was used to adjust the volume to $400 \mu \mathrm{l}$ and proteinase $\mathrm{K}$ was added to $0.5 \mathrm{mg} / \mathrm{ml}$. Samples were then incubated 
for $1 \mathrm{~h}$ at $50^{\circ} \mathrm{C}$, extracted twice with phenol/chloroform/isoamyl alcohol $(25: 24: 1)$ and once with chloroform/isoamyl alcohol $(24: 1)$ alone. DNA was precipitated from these samples by adding $10 \mu \mathrm{l}$ of $5 \mathrm{M} \mathrm{NaC}$ plus $1 \mathrm{ml}$ of ice-cold $100 \%$ ethanol and incubating at $-70^{\circ} \mathrm{C}$ for $>20$ min. DNA was collected by centrifugation, dried on a Savant Speed Vac (Savant Instruments, Inc., Holbrook, NY) and resuspended in $30 \mu \mathrm{l} \mathrm{TE}$ buffer containing $300 \mu \mathrm{g}$ DNase-free RNase A. DNA concentrations were determined spectrophotometrically $\left(A_{260}\right)$. Ratios of absorbance at $260 \mathrm{~nm} / 280 \mathrm{~nm}$ consistently gave values of $\approx 1.8$, reflective of high purity of DNA.

\section{DNA end labeling}

Low molecular weight DNA for end-labeling was prepared as described for conventional gel electrophoresis except that further purification was obtained by performing two phenol/chloroform extractions and one chloroform extraction, followed by precipitation with 0.2 volume of $3 \mathrm{M}$ sodium acetate $(\mathrm{pH} 5.2)$ and 2 volumes $100 \%$ ethanol at $-70^{\circ} \mathrm{C}$, washing twice with $80 \%$ ethanol, drying, and resuspending in ultrapure water. End-labeling of $3^{\prime}$ termini was accomplished using terminal deoxynucleotidyl transferase and $\left[\alpha^{32} \mathrm{P}\right.$ dideoxyATP] diluted 1:8 with $3.4 \mathrm{mM}$ non-radioactive ddATP (in $10 \mathrm{mM}$ Tris, $\mathrm{pH}$ 7.4). The reaction was performed in a total volume of $50 \mu$ l containing $0.5 \mu \mathrm{g}$ DNA, $1 \times$ reaction buffer, $2.5 \mathrm{mM} \mathrm{CoCl}_{2}$ (both supplied with the enzyme), $25 \mathrm{U}$ terminal deoxynucleotidyl transferase, and $5 \mu$ l of diluted $\left[\alpha^{32} \mathrm{P}\right.$-ddATP] for $60 \mathrm{~min}$ at $37^{\circ} \mathrm{C}$. The reaction was terminated by addition of $5 \mu \mathrm{l}$ of $0.25 \mathrm{M}$ EDTA. Ultrapure glycogen ( $1 \mu \mathrm{l}$ of $20 \mathrm{mg} / \mathrm{ml}$ stock) was then added as carrier and the DNA precipitated with 0.2 volume of $10 \mathrm{M}$ ammonium acetate and 3 volumes of cold $100 \%$ ethanol at $-70^{\circ} \mathrm{C}$. The DNA was pelleted, dried, resuspended in water and precipitated once more with ammonium acetate and ethanol in the absence of additional glycogen. The dried pellet was resuspended in $40 \mu \mathrm{l}$ of TE buffer (10 mM Tris, 1 mM EDTA, pH 7.4). DNA (20 $\mu$ l) was then separated by electrophoresis through a $1.8 \% \mathrm{gel}$ in $0.5 \times$ TPE $(40 \mathrm{mM}$ Trisphosphate, $4 \mathrm{mM}$ EDTA) buffer, dried overnight without heat and subjected to autoradiography.

To label $\approx 30-50 \mathrm{~Kb}$ DNA fragments, a $2.0 \mathrm{~mm}$ slice of the preparatory agarose plus was dialyzed extensively in $50 \mathrm{ml}$ ultrapure DEPC $-\mathrm{H}_{2} \mathrm{O}$ and submerged in $50 \mu \mathrm{l}$ of the endlabeling reaction described above. The plug was then incubated in this reaction for $2 \mathrm{~h}$ at $37^{\circ} \mathrm{C}$ in a humidified chamber prior to addition of $20 \mu \mathrm{l}$ of $0.5 \mathrm{M}$ EDTA. The plug was then washed twice in $50 \mathrm{ml} \mathrm{H}_{2} \mathrm{O}$, equilibrated in $0.5 \times$ TBE $(89 \mathrm{mM}$ Tris, $89 \mathrm{mM}$ boric acid, $2.5 \mathrm{mM}$ EDTA) and subjected to pulsed field electrophoresis. Gels were dried $8 \mathrm{~h}$ and subjected to autoradiography.

\section{Plasmid degradation assay}

To assess the degradation of plasmid by thymocyte extract $1 \mu \mathrm{g}$ linearized pUC18 plasmid was added to tubes containing $50 \mathrm{mM}$ Tris, $1 \mathrm{mM} \mathrm{MgCl} 2,1 \mathrm{mM} \mathrm{CaCl}_{2}, 10 \mu \mathrm{g}$ thymocyte nuclear extract and various inhibitors. Samples were incubated for $5 \mathrm{~h}$ at $37^{\circ} \mathrm{C}$. Proteinase $\mathrm{K}(20 \mu \mathrm{g})$ was then added and samples incubated an additional hour at $55^{\circ} \mathrm{C}$ prior to electrophoresis for $1.5 \mathrm{~h}(80 \mathrm{~V})$ on a $1 \%$ agarose ge $(0.5 \times$ TPE buffer). DNA was then visualized by ethidium bromide staining.

\section{Electrophoresis}

For conventional analysis, $1.5 \mu \mathrm{g}$ of HeLa DNA was added to $1.8 \%$ agarose gels immersed in $0.5 \times$ TPE and electrophoresed for $3.25 \mathrm{~h}$ at $80 \mathrm{~V}$. For pulsed field analysis, a $2.0 \mathrm{~mm}$ slice of the preparatory agarose plug was equilibrated in $0.5 \times$ TBE buffer ( $89 \mathrm{mM}$ Tris, $89 \mathrm{mM}$ boric acid, $2.5 \mathrm{mM}$ EDTA), placed against a gel comb and $1 \%$ molten agarose solidified around the plugs. The gel was placed in a Clamped Homogenous Electric Field (CHEF) pulsed field system (Bio-Rad Laboratories, Hercules, $\mathrm{CA}$ ) filled with $0.5 \times \mathrm{TBE}$ and allowed to equilibrate to $14^{\circ} \mathrm{C}$ prior to electrophoresis for $19 \mathrm{~h}$ at $6.0 \mathrm{~V} / \mathrm{cm}$ with a linear switch interval ramp from $0.5-45.0 \mathrm{~s}$. The parameters were chosen to optimally separate DNA fragments ranging from $10-500 \mathrm{~Kb}$ ((Birren and Lai, 1993), E. Lai, personal communication, information also available from Bio-Rad), and we have previously shown that these parameters provide a linear separation of fragments in the target size (Hughes and Cidlowski, 1997). All gels were stained with $1 \mathrm{mg} / \mathrm{ml}$ ethidium bromide and photographed (Polaroid type 55 film) using UV transillumination.

\section{References}

Alnemri ES and Litwack G (1990) Activation of internucleosomal DNA cleavage in human CEM lymphocytes by glucocorticoid and novobiocin. Evidence for a nonCa2+-requiring mechanism(s). J. Biol. Chem. 265: 17323-17333

Barry MA and Eastman A (1993) Identification of deoxyribonuclease II as an endonuclease involved in apoptosis. Arch. Biochem. Biophys. 300: 440-450

Birren B and Lai E (1993) Pulsed Field Gel Electrophoresis: A Practical Guide, Editor, eds. (San Diego, CA: Academic Press, Inc.)

Bradford MM (1976) A rapid and sensitive method for the quantitation of microgram quantities of protein utilizing the principle of protein-dye binding. Anal. Biochem. 72: $248-254$

Chang TW and Eisen HE (1980) Effects of N-tosyl-L-lysyl-chloromethylketone on the activity of cytolytic T lymphocytes. J. Immunol. 124: 1028-1033

Clawson GA, Norbeck LL, Hatem CL, Rhodes C, Amiri P, McKerrow JH, Patierno SR and Fiskum $\mathrm{G}$ (1992) $\mathrm{Ca}^{2+}$-regulated serine protease associated with the nuclear scaffold. Cell Growth Differ. 3: 827-838

Compton MM and Cidlowski JA (1986) Rapid in vivo effects of glucocorticoids on the integrity of rat lymphocyte genomic deoxyribonucleic acid. Endocrinology 118 : $38-45$

Deng G and Podack ER (1995) Deoxyribonuclease induction in apoptotic cytotoxic T lymphocytes. FASEB J. 9: 665-669

Eastman A (1994) Deoxyribonuclease II in apoptosis and the significance of intracellular acidification. Cell Death Differ. 1:7-10

Enari M, Sakahira H, Yokoyama H, Okawa K, Iwamatsu A and Nagata S (1998) A caspase-activated DNase that degrades DNA during apoptosis, and its inhibitor ICAD. Nature 391: 43-50

Hallick R, Chelm B, Gray P and Orozco E (1997) Use of aurintricarboxylic acid as an inhibitor of nucleases during nucleic acic isolation. Nucleic Acid Res. 4: 30553064

Hughes Jr FM and Cidlowski JA (1996) The Enzymology of Apoptosis. In: Apoptosis in Normal Development and Cancer, M. Sluyser, ed. (Bristol, PA: Taylor and Francis, Ltd.), p. $21-38$

Hughes Jr FM and Cidlowski JA (1997) Utilization of an in vitro apoptosis assay to evaluate chromatin degradation by candidate apoptotic nucleases. Cell Death Differ. 4: 200-208

Kaufmann SH, Desnoyers S, Ottaviano Y, Davidson NE and Poirier GG (1993) Specific proteolytic cleavage of poly(ADP-ribose) polymerase: an early marker of chemotherapy-induced apoptosis. Cancer Res. 53: 3976-3985

Khodarev NN and Ashwell JD (1996) An inducible lymphocyte nuclear $\mathrm{Ca}^{2+} / \mathrm{Mg}^{2+}$. dependent endonuclease associated with apoptosis. J Immunol 156: 922-931

Kwo P, Patel T, Bronk SF and Gores SJ (1995) Nuclear serine protease activity contributes to bile acid-induced apoptosis in hepatocytes. Am. J. Physiol 268: G613-G621

Liu X, Zou H, Slaughter C and Wang X (1997) DFF, a heterodimeric protein that functions downstream of caspase-3 to trigger DNA fragmentation during apoptosis. Cell 89: 175-184

Martin SJ and Green DR (1995) Protease activation during apoptosis, death by a thousand cuts? Cell 82: $349-352$

McConkey DJ, Hartzell P, Nicotera P and Orrenius S (1989) Calcium-activated DNA fragmentation kills immature thymocytes. FASEB 3: 1843-1849 
Montague JW, Hughes Jr FM and Cidlowski JA (1997) Native recombinant cyclophilins A, B, and C degrade DNA independently of peptidylprolyl cis-trans isomerase activity: Potential roles of cyclophilins in apoptosis. J. Biol. Chem. 272: $6677-6684$

Nieto MA and Lopez-Rivas A (1989) IL-2 protects T lymphocytes from glucocorticoidinduced DNA fragmentation and cell death. J. Immunol. 143: 4166-4170

Nikonova LV, Beletsky IP and Umansky SR (1993) Properties of some nuclear nucleases of rat thymocytes and their changes in radiation-induced apoptosis. Eur. J. Biochem. 215: 893-901

Oberhammer F, Wilson JW, Dive C, Morris ID, Hickman JA, Wakeling AE, Walker PR and Sikorska M (1993) Apoptotic death in epithelial cells: cleavage of DNA to 300 and/or $50 \mathrm{~kb}$ fragments prior to or in the absence of internucleosomal fragmentation. EMBO J. 12: 3679-3684

Pandey S, Walker PR and Sikorska M (1994) Separate pools of endonuclease activity are responsible for internucleosomal and high molecular mass DNA fragmentation during apoptosis. Biochem. Cell Biol. 72: 625-629

Pandey S, Walker PR and Sikorska M (1997) Identification of a novel 97 kDa endonuclease capable of internucleosomal DNA cleavage. Biochem. 36: 711 720

Patel G, Gores GJ and Kaufmann SH (1996) The role of proteases during apoptosis. FASEB J. 10: 587-597

Peitsch MC, Polzar B, Tschopp J and Mannherz HG (1994) About the involvement of deoxyribonuclease I in apoptosis. Cell Death Differ. 1: 1-6

Ribeiro JM and Carson DA (1993) $\mathrm{Ca}^{2+} / \mathrm{Mg}^{2+}$-dependent endonuclease from human spleen: purification, properties, and role in apoptosis. Biochemistry 32: $9129-$ 9136.

Schwartzman RA and Cidlowski JA (1991) Internucleosomal deoxyribonucleic acid cleavage activity in apoptotic thymocytes: detection and endocrine regulation. Endocrinology 128: 1190-1197
Schwartzman RA and Cidlowski JA (1993) Mechanism of tissue-specific induction o internucleosomal deoxyribonucleic acid cleavage activity and apoptosis by glucocorticoids. Endocrinology 133: 591-599

Shiokawa D, Ohyama H, Yamada T, Takahashi K and Tanuma S-I (1994) Identification of an endonuclease responsible for apoptosis in rat thymocytes. Eur. J. Biochem. 226: 23-30

Squier MK and Cohen JJ (1997) Calpain, an upstream regulator of thymocyte apoptosis. J. Immunol. 158: 3690-3697

Sun X-M and Cohen GM (1994) $\mathrm{Mg}^{2+}$-dependent cleavage of DNA into kilobase pai fragments is responsible for the initial degradation of DNA in apoptosis. J. Biol. Chem. 269: 14857-14860

Walker PR and Sikorska M (1993) Role of proteolysis in apoptosis: involvement of serine proteases in internucleosomal DNA fragmentation in immature thymocytes. Biochem. Cell Biol. 71: 488-500

Walker PR, Weaver VM, Lach B, LeBlanc J and Sikorska M (1994) Endonuclease activities associated with high molecular weight and internucleosomal DNA fragmentation in apoptosis. Exp. Cell. Res. 213: 100-106

Weaver VM, Carson CE, Walker PR, Chaly N, Lach B, Raymond Y, Brown DL and Sikorska M (1996) Degradation of nuclear matrix and DNA cleavage in apoptotic thymocytes. J. Cell. Sci. 109: 45-56

Whyte M (1996) ICE/CED-3 proteases in apoptosis. Trends Cell Biol. 6: 245-248

Wright SC, Wei QS, Zhong J, Zheng H, Kinder DH and Larrick JW (1994) Purification of a $24-\mathrm{kD}$ protease from apoptotic tumor cells that activates DNA fragmentation. J. Exp. Med. 180: 2113-2123 